\title{
ZÁCHRANNÝ ARCHEOLOGICKÝ VÝZKUM NA PŘEDHRADÍ VRACLAVSKÉHO HRADIŠTĚ
}

\author{
DAVID VÍCH
}

Abstrakt: V roce 2014 proběhl záchranný archeologický výzkum na předhradí raně středověkého hradiště v k. ú. Vraclav (Pardubický kraj). Výzkum vyvolalo sesvahování stěny někdejšiho lomu na opuku nad čp. 112 spojené se záborem plochy predhradí. Bylo prozkoumáno sedm objekti̊ zahloubených do skalního podloži datovaných do 11.-12. století a splachová vrstva z mladšího úseku raného stredověku.

Klíčová slova: Vraclav-záchranný archeologický výzkum - raný středověk - hradiště.

\section{Rescue Archaeological Research in the Vraclav Hillfort Bailey}

Abstract: Rescue archaeological research was conducted in 2014 in the bailey of an early-medieval hillfort in the Vraclav cadastral zone (Pardubice Region). The research was triggered by the slide of a wall of a former plaener quarry above house no. 112, connected with the development of the bailey area. Seven features sunken in rocky subsoil and dated to the 11th-12th centuries were investigated, as well as a sheet-wash layer from the later period of the early Middle Ages.

Key words: Vraclav - rescue archaeological research - early Middle Ages - hillfort.

\section{Př́rodní podmínky a historie lokality}

Katastrální území Vraclav se nachází při samém hrotu Vraclavského hřbetu, který odděluje Litomyšlský úval, představující přirozený komunikační prostor na severozápadní Moravu, od Chrudimské tabule, přestavující tradiční sídelní oblast obývanou lidmi již od pravěku (k morfologii Demek-Mackovčin 2006). Četné ostrožny modelované hluboce zaříznutými údolími na severním a především západním okraji Vraclavského hřbetu skýtaly v různých dobách řadu příležitostí pro založení opevnění. Jedním z takových míst osídleným již hluboko v pravěku je ostrožna vytvořená hlubokými údolími na soutoku dvou drobných vodotečí nacházející se poblíž dnešního jádra obce Vraclav (obr. 1). Opukovou skálu zde kryje nepříliš mocný sprašový pokryv, s nímž se setkáváme i v širším okolí Vraclavi (Válek 1964).

Snad již koncem doby bronzové či ve starší době železné zde vzniklo sídliště a pravděpodobně i hradiště, ale pro to zatím stále chybí důkazy v podobě řezu valem. Do nejvýznamnějšího úseku svých dějin však vstoupila lokalita v 11. století, kdy zde vzniklo raně středověké hradiště plnící funkci správního, hospodářského a mocenského centra vládnoucích Přemyslovců. V souvislosti s hlubokými společenskými změnami toto centrum ve 13. století zaniklo, počátkem 14. století je v kronice takřečeného Dalimila uváděno hradiště jako pusté (k písemným pramenům souhrnně Sláma 1986, 94; Ježek-Sommer 2001, 97-95).

Archeologické výzkumy na hradišti prováděl na přelomu 19. a 20. století J. L. Píč $(1909,350)$, poté pak v první polovině 60. let minulého století položili na akropoli několik sond L. Hrdlička a L. Skružný. Při této příležitosti podal druhý z jmenovaných stručný přehled poznatků o lokalitě (Skružný 1962), vlastní výzkum se však dosud nedočkal zhodnocení.

Nedílnou součástí hradiště bylo i předhradí, o němž však nejenže nevíme prakticky nic, ale dokonce vlastně ani s jistotou nevíme, kolik předhradí vraclavské hradiště skutečně mělo (Čtverák-Lutovský-Slabina-Smejtek 2003, 346). Určitou roli v tom sehrál areál zemědělského družstva, který zastavěl a do jisté míry zničil značnou část předpolí hradiště včetně části předhradí. V areálu předhradí jsme přitom dosud registrovali jedinou archeologickou akci, která zachytila intaktní situace, a to výkop pro vodovod dokumentovaný V. Vokolkem (1954).

V posledních dvou desetiletích se pozornost archeologů přesunula do bezprostředního zázemí hradiště, a to především v souvislosti s terénními zásahy vyvolanými stavební činností. Registrovat se tak podařilo četné aktivity především ze 13. století v prostoru kolem jádra stávající obce (sídlištní situace v interiéru čp. 8 - Vokolek 1996; vrstva ze 13. století kryjící starší 


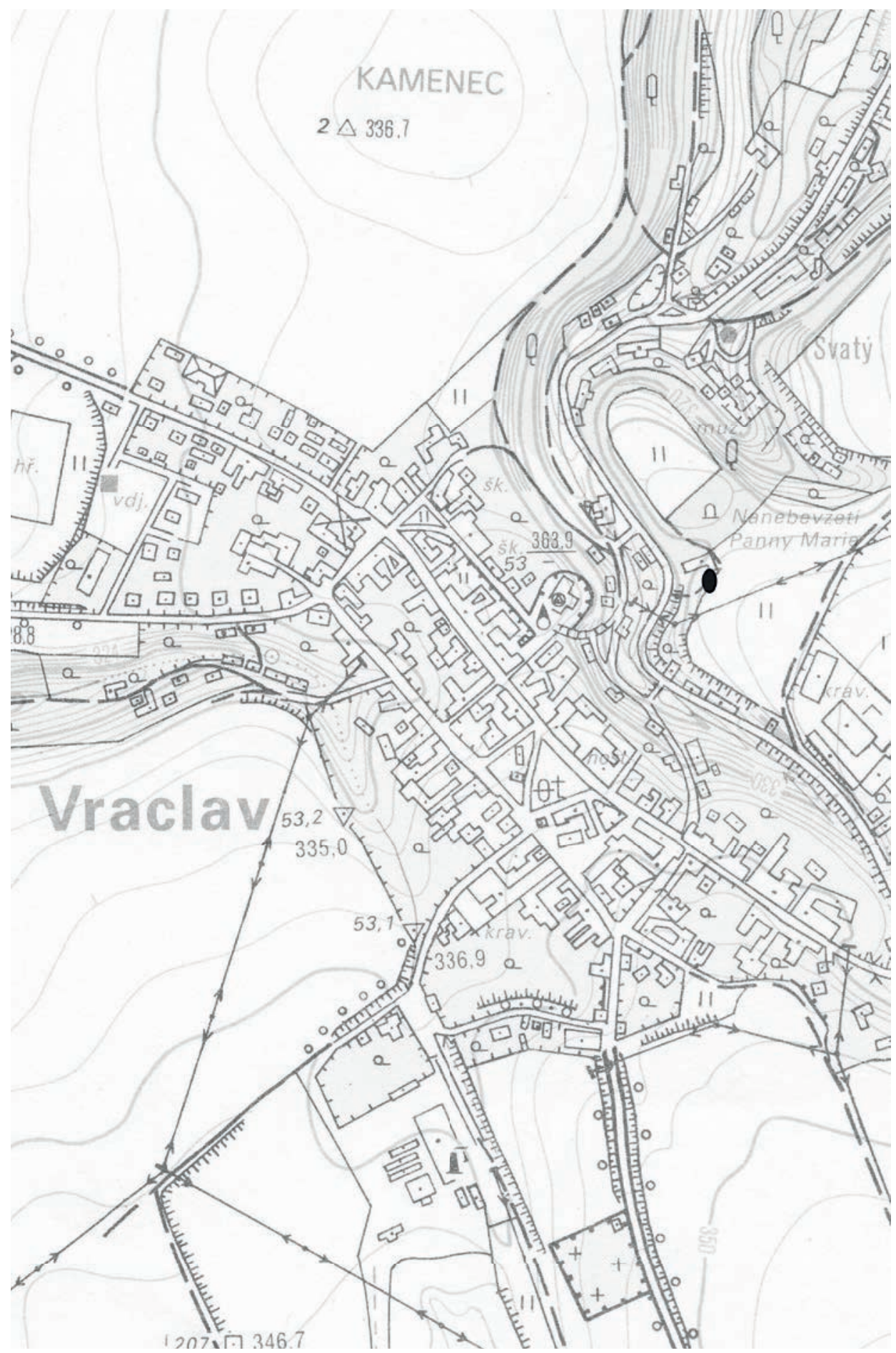

Obr. 1. Vraclav. Poloha výzkumu na předhradí hradiště.

Abb. 1. Vraclav. Lage der Grabung auf der Vorburg des Burgwalls. 
hrob zjištěná při př́istavbě základní školy - Vích 2008; studna zjištěná v průběhu rekonstrukce návsi - Vích 2010). Přri stavbě rodinného domu při silnici směřující od vraclavského hradiště směrem na Janovičky zdokumentovala M. Beková několik stavbou těžce narušených hrobů z mladší doby hradištní obsahujících esovité záušnice (1999). Prezentovaný výzkum je tak pokračováním řady akcí vyvolaných terénními zásahy v katastrálním území této obce.

Jediný badatelský výzkum realizovaný na katastru mimo hradiště se uskutečnil u bývalého kostela sv. Václava situovaného pobliž návsi. Výzkum sice vyloučil středověké stáří nadzemních zdí i struktur zachycených výzkumem pod zemí, ale zjistil př́itomnost pohřebiště snad již raně středověkého stáří (Ježek-Sigl-Vokolek 1998; Ježek-Sommer 2001). Širšímu okolí vraclavského hradiště v raném středověku se z různých úhlů věnoval Petr Charvát (1978), počet archeologických pramenů se dále postupně rozrůstá, byt’ jde většinou o sběrové nálezy (Vích 2000), v posledních letech doplňované detektorovou prospekcí.

\section{Výzkum na předhradí v roce 2014}

Situaci v poznávání předhradí poněkud změnil až záměr majitelů čp. 112 (rodina Pytlíkova) $\mathrm{v}$ roce 2014. Jejich dům je jako jediný situován mezi akropolí a přehradím pod umělou skalní stěnou vzniklou jako pozůstatek lámání kamene v blíže neurčené době, pravděpodobně však v 19. století s rozmachem zdejší kamenné rustikální architektury. Z obnažené skály se vlivem přírodních procesů postupně uvolňovaly kameny, které obyvatele zmíněného domu ohrožovaly na majetku i životě, a proto mělo dojít k sesvahování uvedené stěny včetně záboru zhruba $4 \mathrm{~m}$ širokého pruhu nedotčeného terénu (obr. 1). Tato skutečnost vyvolala záchranný výzkum plně financovaný z prostředků Regionálního muzea ve Vysokém Mýtě. Výzkum prováděli pracovníci této instituce spolu s najatým brigádníkem.

Na ploše využívané dnes jako louka jsme nejprve vytyčili sondu 1/2014 o rozměrech $2 \times 15,5 \mathrm{~m}$ (později o $0,5 \mathrm{~m}$ ještě prodlouženou jihozápadním směrem) s následným rozdělením na jednotlivé úseky A-D, každý o délce 3,5 m, a 0,5 m široké kontrolní bloky (obr. 2). Vzhledem k významu lokality a naorávané kulturní vrstvě pravidelně registrované na zemědělsky obdělávané ploše předhradí bezprostředně sousedící s plochou výzkumu bylo přikročeno k ruční skrývce ornice a - jak se později ukázalo - zčásti také navážek (vrstvy 101 a 105). Nároží jednotlivých úseků sondy 1/2014 byla označena čísly C1-C16. Prostor mezi sondou 1/2014 a skalní stěnou spadající k čp. 112 jsme rozdělili na sondy 2/2014 a 3/2014. Bohužel, kulturní vrstva se oproti původnímu předpokladu nedochovala a nadložní ornice s navážkami obsahujícími nálezy z mladší doby hradištní, vrcholného středověku a novověku včetně subrecentních nálezů zde nasedá prrímo na skalní opukové podloží. Do něj byly zahloubeny jednotlivé objekty, jež jsme označili postupně čísly 1-6, 8/2014 (obr. 3, 4). Při skrývce sektoru C a především sektoru D se pod až 0,75 m mocnou navážkou vyrýsovala situace, která byla označena jako objekt 7/2014 (obr. 5-6). S postupným odkryvem jsme však zjistili, že jde o přirozeně či uměle skloněné skalní podloží kryté uloženinami 102-104 s nálezy (spíše z mladšího úseku) mladší doby hradištní. Skutečný rozsah dané situace se nepodařilo zjistit, protože východním směrem pokračovala situace, označená jako obj. 7/2014, mimo zkoumanou plochu, severně ji zničila hospodářská přístavba domu čp. 112. Od více méně rovné plochy sondy tvořené skalním podložím v úsecích $\mathrm{A}, \mathrm{B}$ a větší části úseku C oddělovala svah objektu 7/2014 rovná hrana sestavená z kvadratických kamenů působící zpočátku dojmem zdi. Záhy se však ukázalo, že jde o hranu přirozené skalní pukliny, přičemž dojem zdi vznikl zvětráváním opukového podloží, které probíhá v plochých deskách, často právě kvadratického tvaru.

Objekty 1-6, 8/2014 jsme prozkoumali v úplnosti po polovinách a přirozených vrstvách s dokumentovanými řezy (obj. 1-6, 8/2014 viz obr. 4; obj. 7/2014 viz obr. 5-6). Pod nárožími sondy v místech bodů $\mathrm{C} 1$ a C16 se nacházely objekty, proto zde byla sonda rozšířena ještě o 0,5 m jižním směrem za účelem úplného prozkoumání zachycených objektů, což se podařilo pouze u objektu 2/2014 pod nárožím C16. Ćást obj. 1/2014 pod nárožím C1 definitivně zůstala mimo skrytou plochu. 


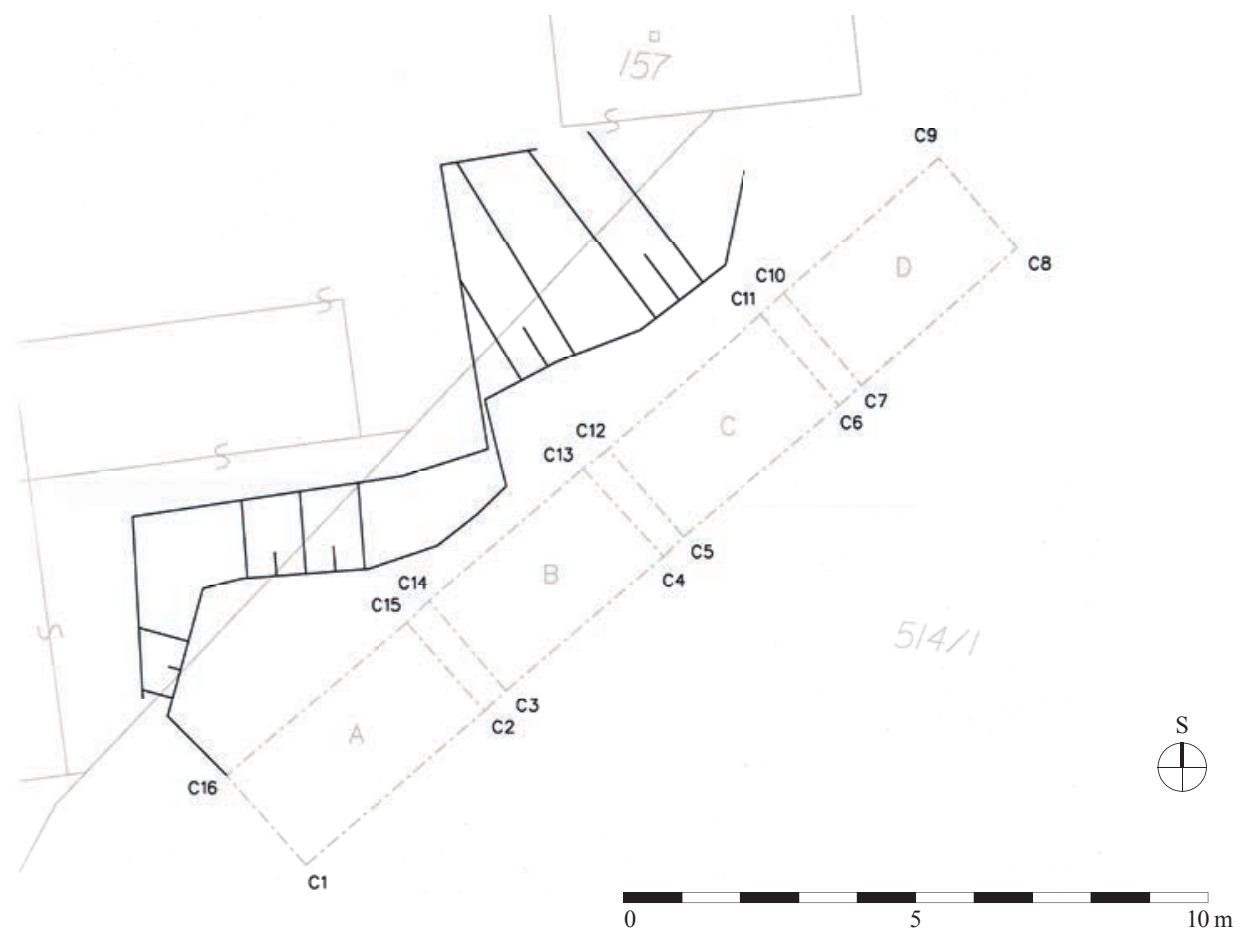

Obr. 2. Vraclav. Geodetické zaměření sondy 1/2014 rozdělené na úseky.

Abb. 2. Vraclav. In Abschnitte unterteilte geodätische Vermessung von Sondiergrabung 1/2014.

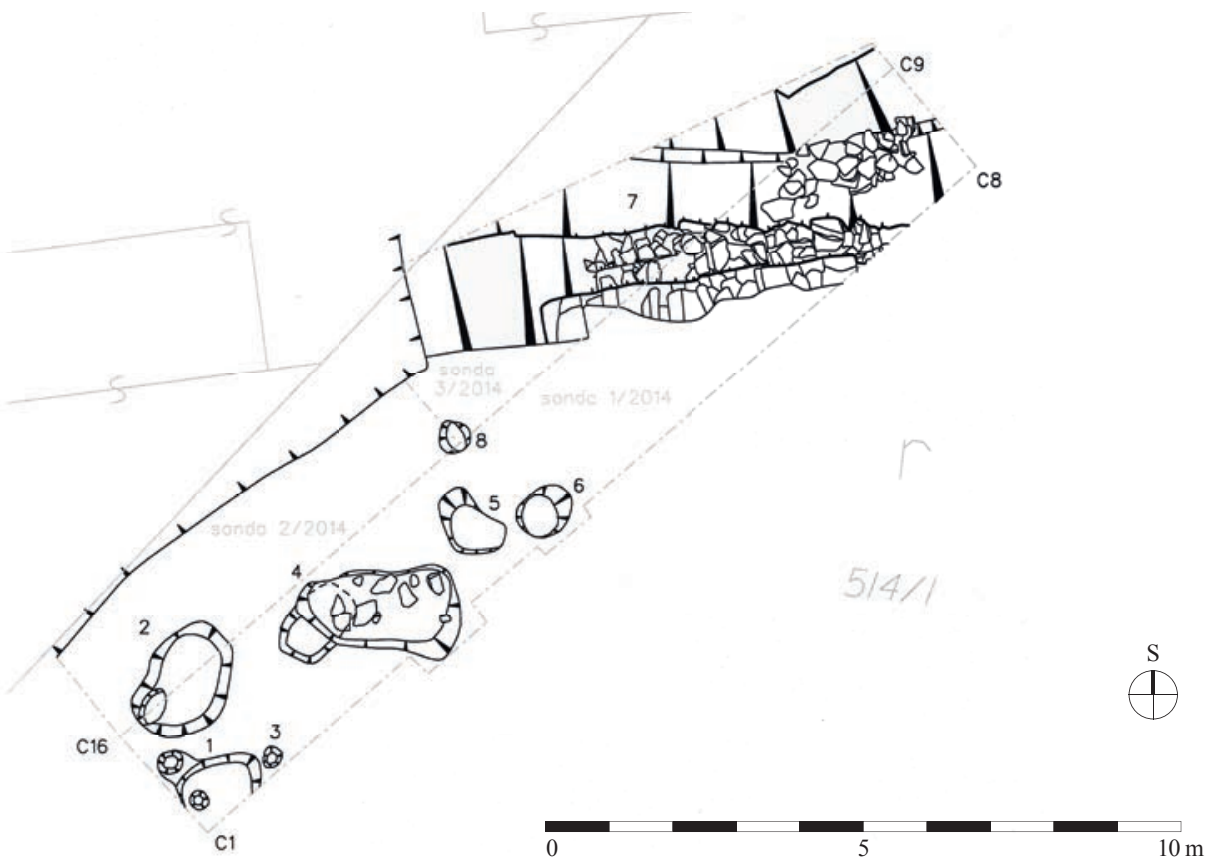

Obr. 3. Vraclav. Geodetické zaměření výzkumu.

Abb. 3. Vraclav. Geodätische Vermessung der Grabung. 
$1 / 2014$
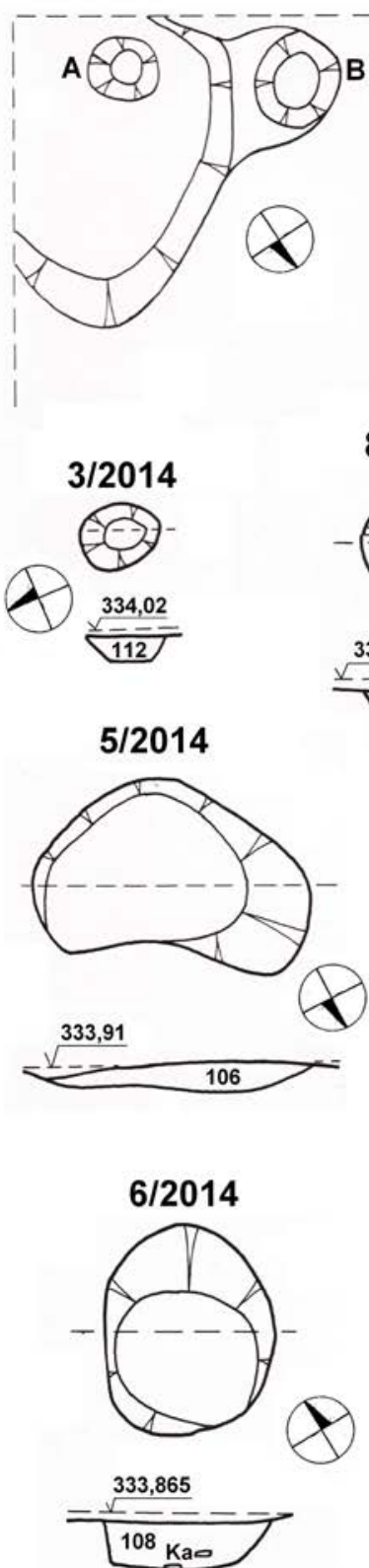

\section{$2 / 2014$}

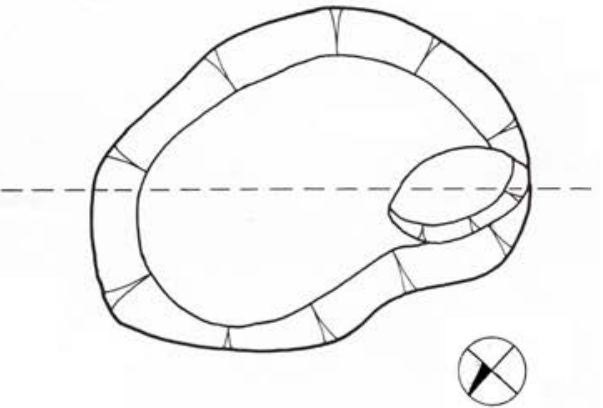

333,975

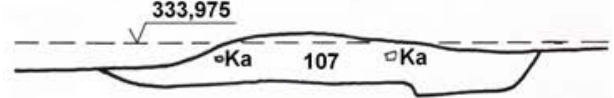

\section{$1 \mathrm{~m}$}

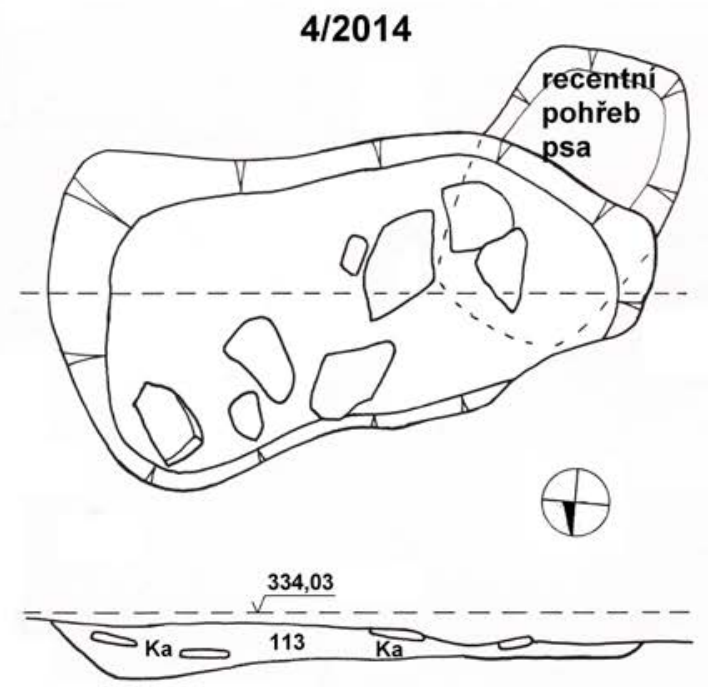

Obr. 4. Vraclav. Kresebná dokumentace objektů 1-6, 8/2014.

Abb. 4. Vraclav. Zeichendokumentation der Objekte 1-6, 8/2014.

V průběhu výzkumu byly odtěžované uloženiny průběžně kontrolovány detektorem kovů XP Deus v režimu Deus fast, popř. Goldmaxx Power II. V př́ipadě nadložních vrstev 101 a 105 jsme s ohledem k zamoření vrstev recentním železem používali přístroj v diskriminačním režimu (tj. s potlačením železa), uloženiny raně středověkého původu jsme přirozeně procházeli v režimu ALL METAL (tj. vyhledávány byly všechny kovové předměty včetně železa). 


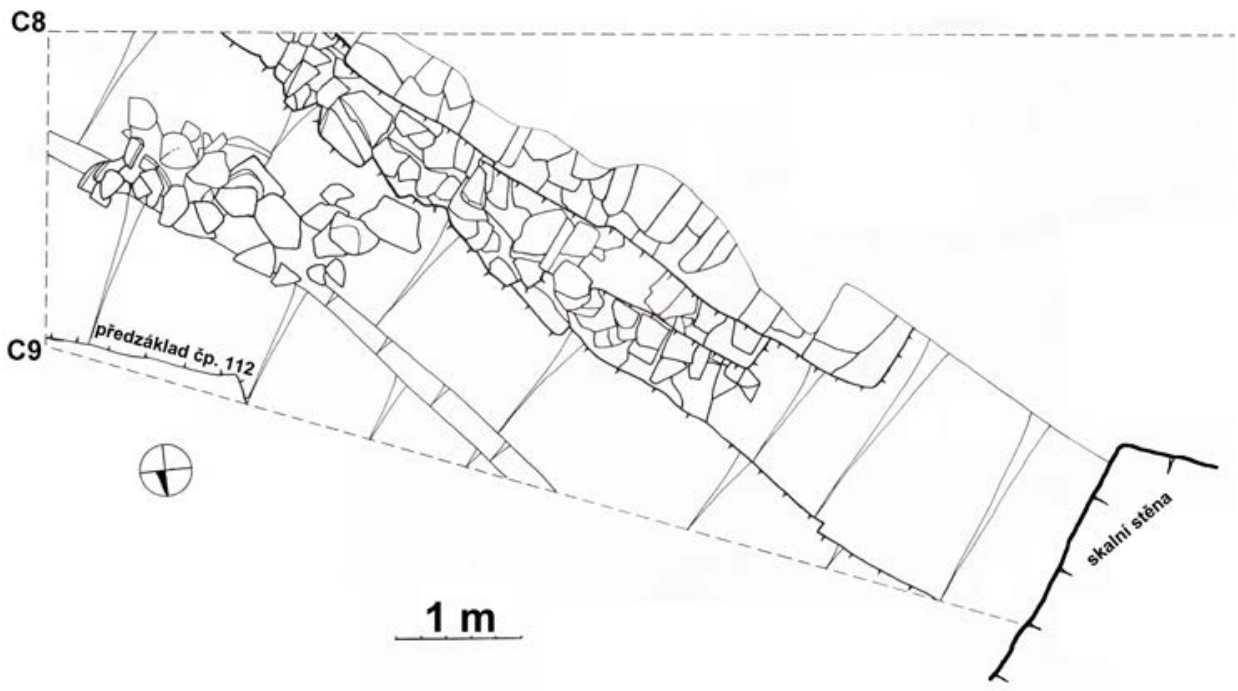

Obr. 5. Vraclav. Kresebná dokumentace objektu 7/2014.

Abb. 5. Vraclav. Zeichendokumentation von Objekt 7/2014.
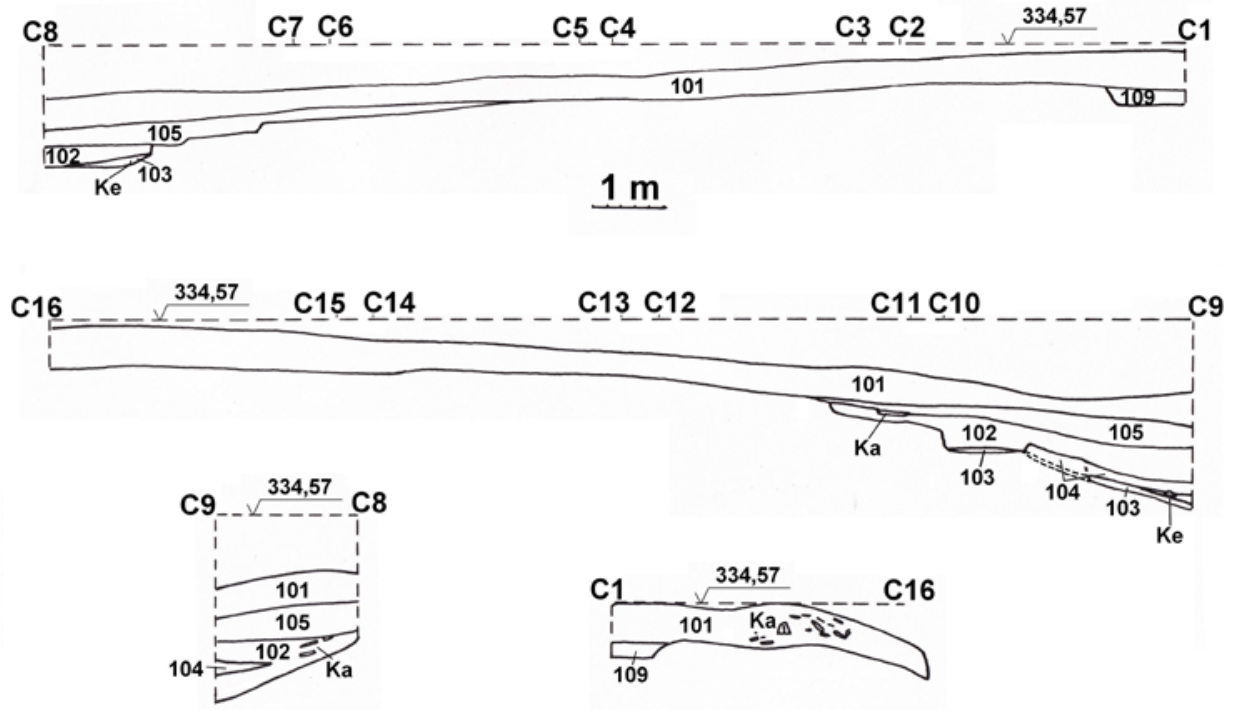

Obr. 6. Vraclav. Kresebná dokumentace řezů v sondě 1/2014.

Abb. 6. Vraclav. Zeichendokumentation der Schnitte von Sondiergrabung 1/2014. 


\section{Popis uloženin}

101 - ornice a navážka s nálezy z raného středověku až novověku

102 - hnědočerná hlinitopísčitá (eluvium) s keramikou, zvířecími kostmi, hlemýždími ulitami, ojedinělou Fe struskou a ojedinělými Fe předměty (nůž, zlomek podkovy, hřeby)

103 - šedookrová - geologické eluvium promísené s uloženinou 102 s ojedinělou větší keramikou, zvírecími kostmi

104 - destrukce opukových kamenů

105 - okrovošedá písčitohlinitá navážka s nálezy raného středověku až novověku

106 - šedá písčitohlinitá promísená s kameny z rozpadlého podloží s ojedinělými zvířecími kostmi a keramikou (výplň objektu 5/2014)

107 - hlinitopísčitá (eluvium) s kameny, keramikou, kostmi (výplň objektu 2/2014)

108 - šedohnědá hlinitopísčitá (eluvium) s keramikou, zvířecími kostmi, kameny (výplň objektu 6/2014)

109 - šedohnědá hlinitopísčitá (eluvium) s keramikou, zvířecími kostmi, uhlíky (výpln̆ objektu 1/2014 a kůlové jámy B u stejného objektu)

110 - šedá hlinitopísčitá (eluvium) s uhlíky (výplň kůlové jámy A v obj. 1/20014)

111 - šedohnědá hlinitopísčitá (eluvium) s keramikou, zvířecími kostmi a kameny (výpln̆ objektu 8/2014)

112 - šedohnědá hlinitopísčitá výplň (eluvium) bez movitých nálezů (výplň objektu 3/2014)

113 - hlinitopísčitá šedohnědá s keramikou, kameny, zvířecími kostmi (výpln̆ objektu 4/2014)

\section{Vyhodnocení nálezů}

\subsection{Movité nálezy}

$\mathrm{V}$ rámci movitých nálezů jsou, jak bývá u archeologických výzkumů středověkých lokalit obvyklé, hlavním pramenem zlomky keramiky, ${ }^{1}$ které můžeme rozdělit do třech skupin.

V souboru drtivě převažuje keramika šedých až hnědavých odstínů, přičemž se často objevuje i rezavě hnědý střep. Obsahuje výrazné písčité ostřivo, běžné je ovšem i ostření drcenou slídou. Vedle výzdoby rytou šroubovicí mající masový charakter se objevuje vlnice provedená jednohrotým i vícehrotým nástrojem a horizontálně řazené vrypy obvykle na hrdlech či podhrdlích nádob, ojediněle výzdoba v podobě různých dolíčků (obr. 10:6; 20:4). Pokud se objeví dna nádob, pak vždy s podsýpkou a nezř́idka nesou hrnčířskou značku (obr. $10: 2 ; 13: 2 ; 16: 1 ; 17: 4)$. Nejčastěji se pochopitelně setkáváme s hrnci (žádný ze zlomků však pro př́lišnou zlomkovitost neumožňuje rekonstrukci celého tvaru) opatřenými obvykle ven vyhnutými svisle až nálevkovitě seříznutými okraji, vně nezesílenými (obr. 11:11; 21:7; 22:7) či zesílenými (např. obr. 8:1, 3; 9:6; $14: 12 ; 18: 4 ; 19: 2)$, někdy zevnitř prožlabenými
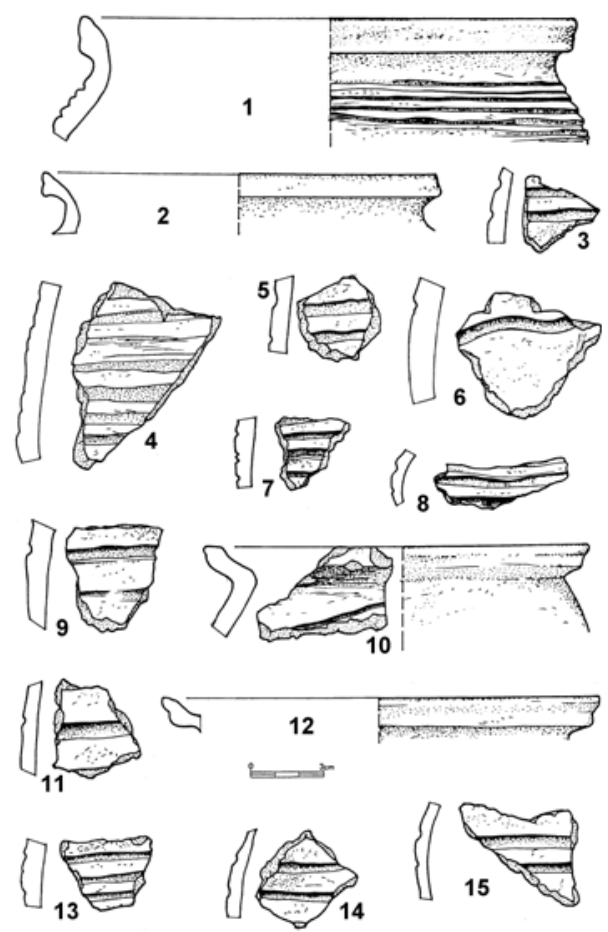

Obr. 7. Vraclav. Nálezy z objektu 1/2014.

Abb. 7. Vraclav. Funde aus Objekt 1/2014.

1 Vzhledem k tomu, že jde o první publikovaný soubor keramiky z intaktních situací z lokality, byl kladen velký důraz na kresebné vyobrazení. Vyobrazeny byly veškeré okraje a výzdoba, pouze u stereotypně se opakující ryté šroubovice byl volen jen ilustrační výběr. 

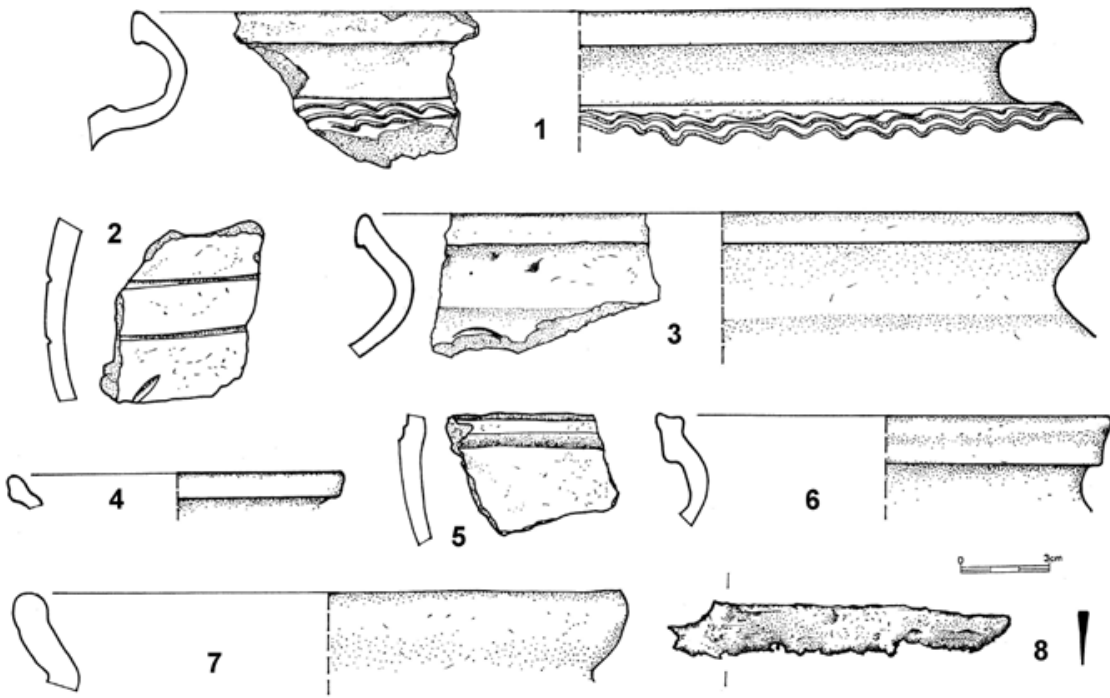

Obr. 8. Vraclav. Nálezy z objektu 2/2014.

Abb. 8. Vraclav. Funde aus Objekt 2/2014.
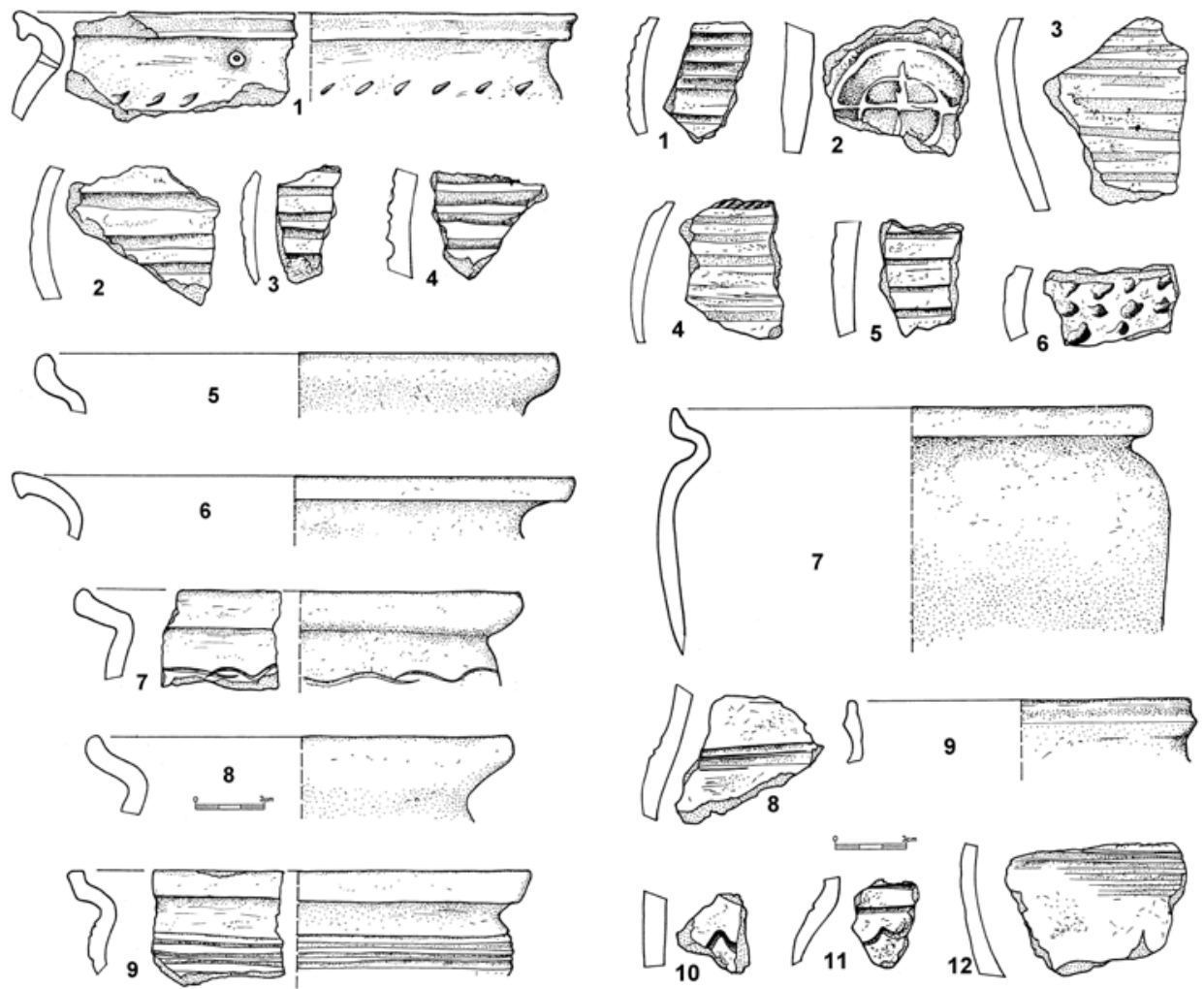

Obr. 9. Vraclav. Nálezy z objektu 2/2014.

Abb. 9. Vraclav. Funde aus Objekt 2/2014.

raclav. Nalezy z objektu 4/2014.

Abb. 10. Vraclav. Funde aus Objekt 4/2014. 


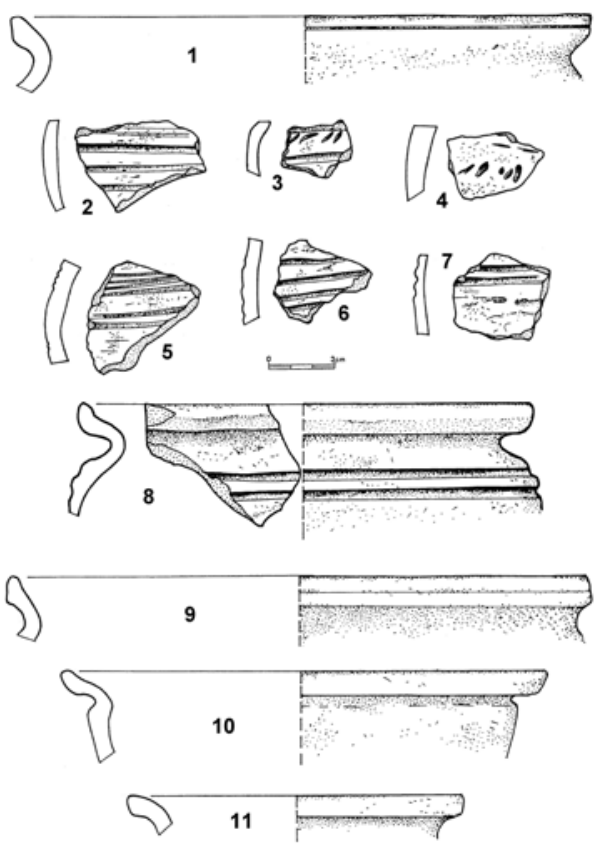

Obr. 11. Vraclav. Nálezy z objektu 4/2014. Abb. 11. Vraclav. Funde aus Objekt 4/2014.

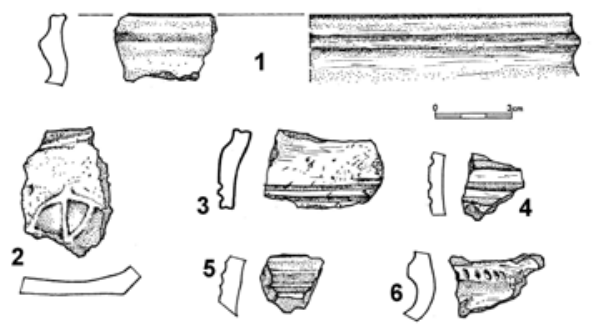

Obr. 13. Vraclav. Nálezy z objektu 5/2014.

Abb. 13. Vraclav. Funde aus Objekt 5/2014.
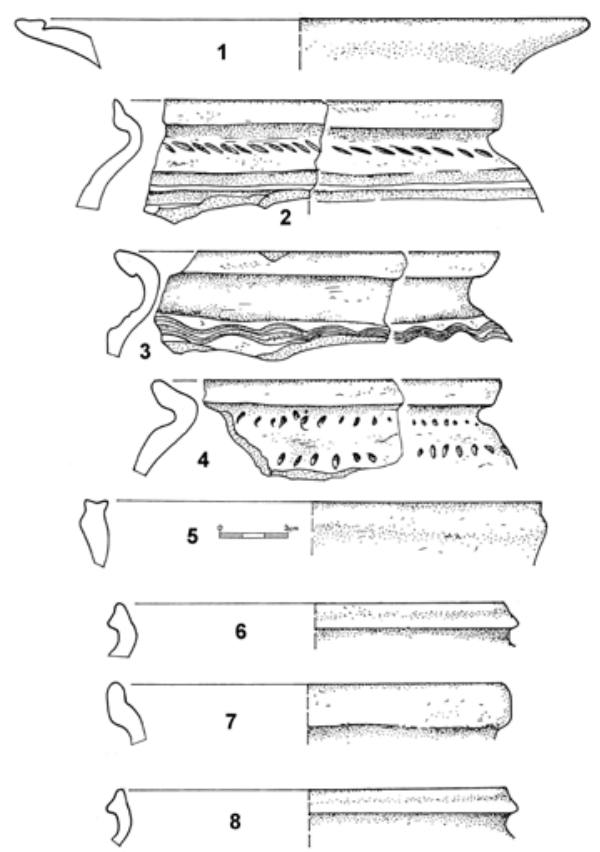

Obr. 12. Vraclav. Nálezy z objektu 4/2014.

Abb. 12. Vraclav. Funde aus Objekt 4/2014.

(např. obr. $8: 4 ; 11: 9 ; 12: 2,8 ; 18: 2,10$ ), popř. dále složitěji utvářenými. Jeden okraj zastupuje misky (obr. 12:1). Tato keramika reprezentuje mladohradištní zboží domácí produkce.

Pouze ojediněle se objevují i zlomky $\mathrm{s}$ výraznou příměsí tuhy $\mathrm{v}$ keramické hmotě, a to většinou na silnostěnném střepu (síla stěny 1-2 cm), které představují zlomky zásobnic včetně jednoho zlomku okraje (obr. 22:1). Grafitová tenkostěnná keramika se vyskytuje v souboru jen vzácně. Jedním kusem je zastoupen nízký římsovitý okraj provedený

v grafitovém materiálu z tzv. obj. 7/2014 (obr. 19:4) představující doklad kontaktů s Moravou (srov. Goš 1977, 293-294, 300; Procházka-Peška 2007, 255, skupina 23). Poznamenejme ještě, že tento stav silně kontrastuje se situací v době okolo 13. století, kdy se na Vysokomýtsku a Litomyšlsku grafitová keramika objevuje v masovém měřítku.

Minoritní, ale nikoliv zcela ojedinělou keramickou skupinu tvoří zlomky hrnců šedé barvy různých odstínů s hustým jemně drceným písčitým ostřivem s kalichovitým okrajem, někdy doplněné výzdobou jednoduché vlnice či rytou šroubovicí (obr. 9:5, 7-8; 10:7; 11:8; 14:2, 11; 17:6). Kalichovitým okrajům a jeho derivátům příznačným pro pražské prostředí byla věnována pro jejich relativní chronologickou citlivost značná pozornost (v posledních desetiletích především Pavlů 1971; Smetánka 1973, 475-477; Čiháková 1984; Hrdlička 1993, 98-101; Boháčová-Čiháková 1994; Hrdlička 1997; Boháčová 2001, 184; 2003, 50, poznámka 5). Tuto keramiku můžeme vnímat jako určitý - s ohledem na uspořádání mocenských poměrů v přemyslovském státě v zásadě nikoliv překvapivý - doklad jistých vazeb mezi východními Čechami a pražskou oblastí. Zda šlo o přímý import keramické produkce, nebo (což se jeví jako pravděpodobnější) o vliv 

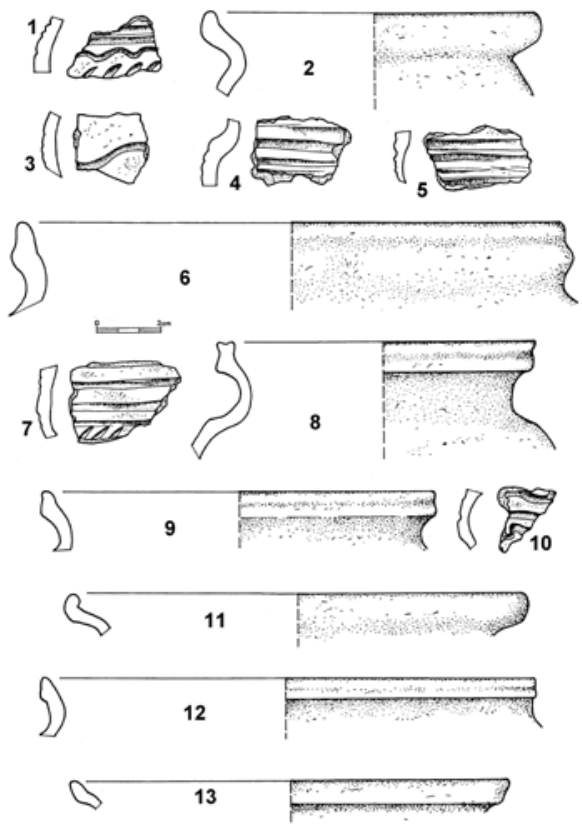

Obr. 14. Vraclav. Nálezy z objektu 6/2014. Abb. 14. Vraclav. Funde aus Objekt 6/2014.

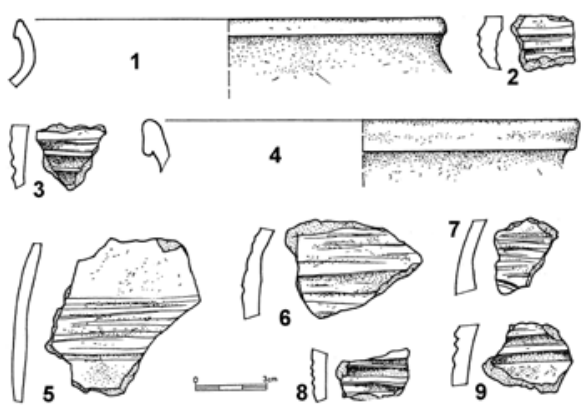

Obr. 15. Vraclav. Nálezy z objektu 6/2014. Abb. 15. Vraclav. Funde aus Objekt 6/2014.
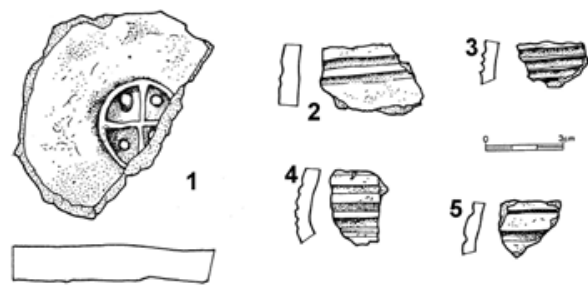

Obr. 16. Vraclav. Nálezy z objektu 8/2014.

Abb. 16. Vraclav. Funde aus Objekt 8/2014.

pražské hrnčířské produkce na místní řemeslníky, zůstává otevřené. Kalichovité okraje pak známe i z dalších raně středověkých východočeských lokalit a patrně nepůjde, jak ostatně naznačuje i prezentovaný soubor, o zcela unikátní záležitost. Bohužel, př́íslušné keramické soubory (až na výjimky, napřr. Chrudim - Frolík-Sigl 1995, 70; Hradec Králové - Richter-Vokolek 1995, 60) zůstávají nepublikované. Studiu kalichovitých okrajů ve východočeském prostředí a jejich případnému vztahu ke středočeské oblasti tak bude třeba v budoucnu věnovat zvýšenou pozornost, a to včetně aplikace př́ŕrodovědných metod.

Získaná keramika celkově dobře reprezentuje východočeské mladohradištní zboží, avšak při snaze o její lepší pochopení narážíme na fakt, že této kategorii pramenů ve východních Čechách věnují badatelé poměrně omezenou pozornost. Nezbývá, než se spokojit s pouze intervalovou datací souboru do doby osídlení hradiště, tedy do 11. a 12. století, a to i přes výskyt kalichovitých okrajů. Ty jsou ve středočeské oblasti kladeny do závěru druhé třetiny 10. století až nejpozději do první poloviny 12. století (Hrdlička 1993, 100; Boháčová-Čiháková 1994, 177; Čiháková 1997, 128; Boháčová 2001, 264; 2003a, 453), jejich chronologickou pozici ve východních Čechách však bude třeba podrobit zevrubnému studiu. Zajímavé by nepochybně bylo rovněž srovnání keramiky z hradiště s keramikou z rovinných sídlišt' v zázemí tohoto mocenského centra. Ovšem taková rovinná sídliště nejenže dosud nebyla archeologicky zkoumána (jedinou výjimku představuje pouze několik jam prozkoumaných autorem v Cerekvici nad Loučnou, ty jsou však oproti materiálu z vraclavského hradiště starší - Vích 2008a), ale nedostatečně je zatím známe i v rámci povrchové prospekce (např. Tisová - Vích 2004; Ŕíkovice - Vích 2012).

Při zpracování keramiky mladší doby hradištní z bezprostředně navazujícího regionu Chrudimska konstatují J. Frolík a J. Sigl dožívaní tradice střední doby hradištní, tedy použití slídového ostřiva, hnědé odstíny povrchu a doznívaní vlnice, zatímco plně vyspělá mladohradištní keramika je zhotovena z keramické hmoty, v níž slídu nahrazuje písčité ostřivo, ve výzdobě dominuje rytá šroubovice někdy kombinovaná s jednoduchou vlnicí a vrypy, přičemž k nástupu nové technologie dochází někdy v pokročilém 11. či na počátku 12. století (Frolík-Sigl 1995, 69-70). V archeologických nálezech z Vraclavska ovšem registrujeme slídové ostřivo hluboko 

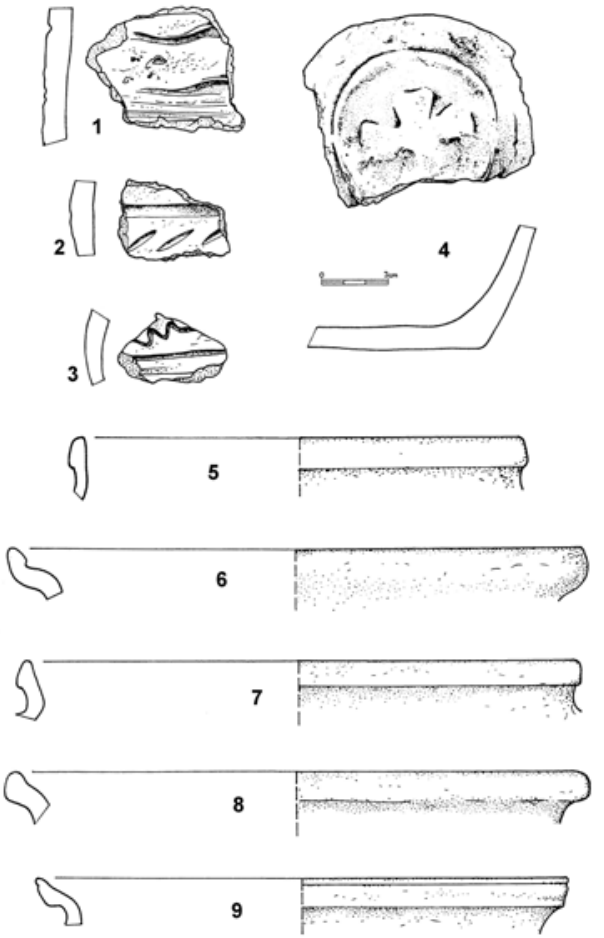

Obr. 17. Vraclav. Nálezy z objektu 7/2014, vrstva 102. Abb. 17. Vraclav. Funde aus Objekt 7/2014, Schicht 102.
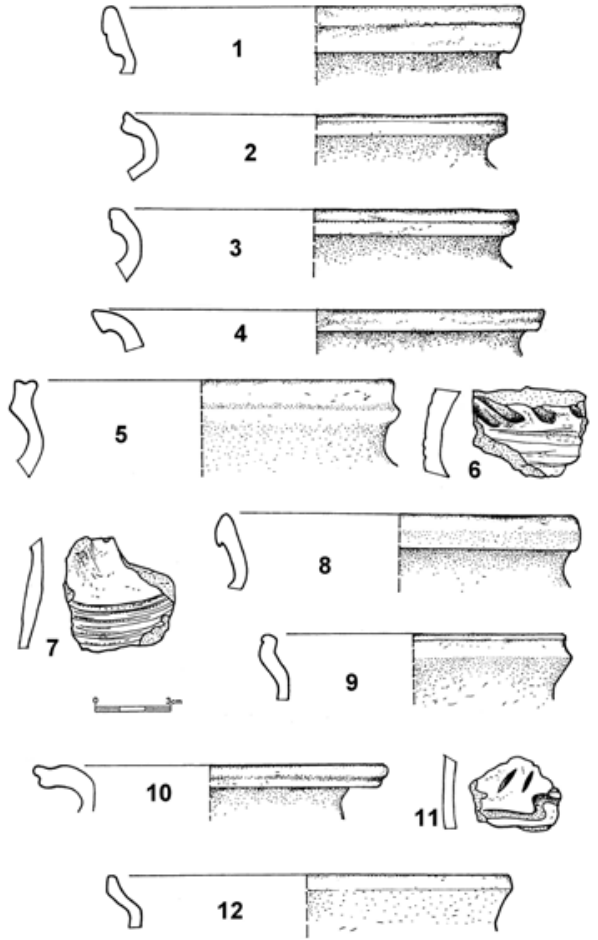

Obr. 18. Vraclav. Nálezy z objektu 7/2014, vrstva 102. Abb. 18. Vraclav. Funde aus Objekt 7/2014, Schicht 102.

do 13. století a ještě na počátku 14. století (nálezy z vrcholně středověké lokality Zářecká Lhota Hrádníky datované kovovými předměty, vrstvy související s dendrochronologicky datovanou strukturou v Litomyšli - Smetanově náměstí u čp. 57, 58, nepublikované výzkumy autora připravované do tisku). Keramika spolehlivě datovatelná do 13. století se ve studované kolekci z Vraclavi neobjevuje, popř. ji při dnešním stavu poznatků nedokážeme spolehlivě identifikovat (srov. s nálezy z Tisové - Starého Mýta - Richter 1994). Snad pouze některé atypické grafitové střepy z tzv. objektu 7/2014 teoreticky připouštějí úvahy o takovémto datování, jde však většinou o atypické zlomky bez větší vypovídací schopnosti.

Železné předměty se dělí na dvě skupiny podle místa nálezu: předměty zjištěné v objektech a předměty zjištěné v souvrství označeném jako objekt 7/2014. První skupinu tvoří pouze čepel nože s odkorodovaným trnem pro naražení rukojeti z organického materiálu z objektu 2/2014 (obr. 8:8). Tyto předměty tvoří běžnou součást hmotné kultury raného středověku, více informací by mohla poskytnout metalografická analýza.

Nevelkou kolekci železných předmětů přinesla vrstva 102. Jde o zlomek podkovy (obr. 21:1), hřeby k připevnění podkov, tzv. podkováky (obr. 21:3-4), dvouramennou skobu (obr. 21:5) a další čepel nože s odkorodovaným trnem (obr. 21:2). Ani v tomto př́ípadě nelze pro zlomkovitost či průběžnost tvaru provést detailnější typologickou analýzu, čehož lze litovat především u zlomku podkovy, protože s podkovami se v raném středověku nesetkáváme zcela běžně. Bohužel, absence středové části a především odlomení konců ramen osazené či neosazené ozuby je zcela limitní. Zmínky zasluhuje pouze čepel nože, na níž je zřetelně patrné navaření břitu z odlišného materiálu, což naznačuje technologicky kvalitnější provedení nástroje, více by prozradil opět pouze metalografický rozbor (srov. Hošek-Šilhová 2006).

Ze svrchní vrstvy 101 pochází hrot šípu s tulejí vrcholně středověkého stáří (obr. 24:1), nalezený dodatečně na výhozu. Tyto hroty jsou považovány za hroty šípů určených ke střelbě 

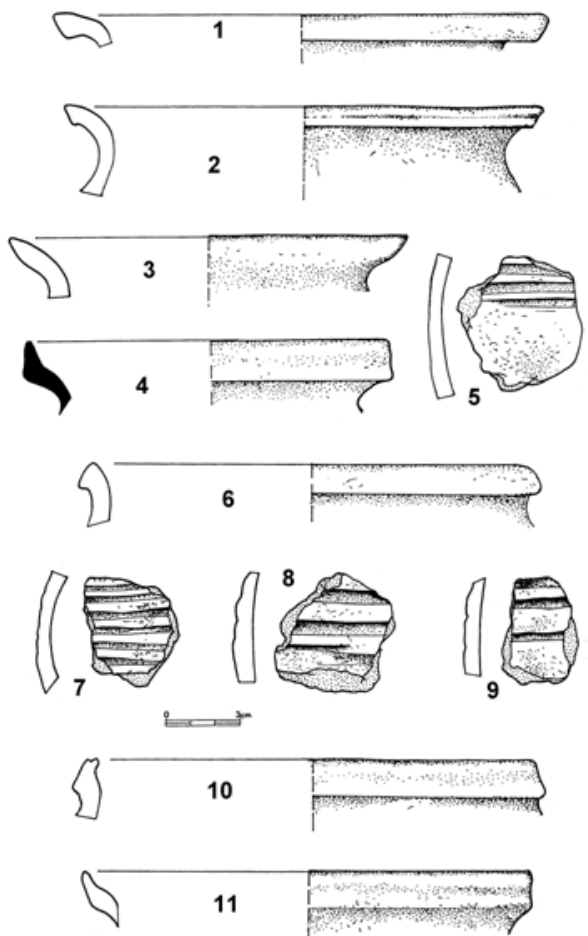

Obr. 19. Vraclav. Nálezy z objektu 7/2014, vrstva 102. Abb. 19. Vraclav. Funde aus Objekt 7/2014, Schicht 102.
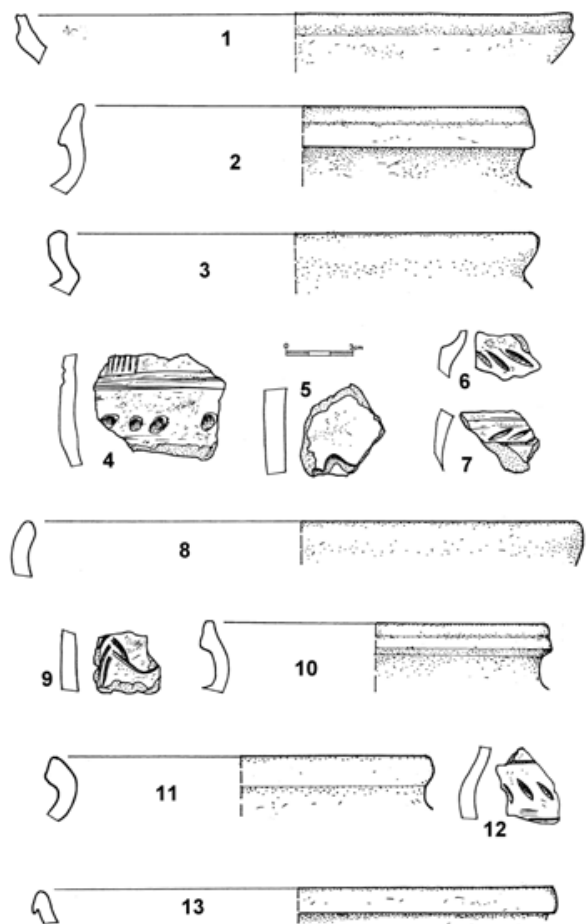

Obr. 20. Vraclav. Nálezy z objektu 7/2014, vrstva 102. Abb. 20. Vraclav. Funde aus Objekt 7/2014, Schicht 102.

ze samostřílu, analogické nálezy z hradiště bezprostředně za jižním valem uvádí L. Skružný (1962, 13, poznámka 29).

Z výzkumu rovněž pochází 169 fragmentů zvírecích kostí a zubů, jejichž určení provedla Gabriela Dreslerová (2015). Dle značné zlomkovitosti jde o kuchyňský odpad, což ovlivnilo výsledky určení. Kosti nesou často stopy okusu masožravcem, vyskytují se i zřetelné stopy řezání. Celkem se podařilo určit šest zvířecích druhů výhradně domácích zvířat. Výrazně zastoupen je tur (Bos primigenius f. taurus), prase (Sus scrofaf. domestica) a ovce/koza (Ovis-Capra). Jedním zubem je zastoupen kůň (Equus caballus) a pažní kostí i pes (Canis lupus f. familiaris), jedna kost pak pochází z husy domácí (Anser anserf. domesticus).

Flotace vzorků výplní objektů přinesla množství uhlíků, patrně pozůstatků palivového dřeva, a rostlinných makrozbytků, jejichž vyhodnocení provedl Jan Novák (2015). V 241 vzorcích uhlíků zjistil jedenáct druhů dřevin, nejčetněji dub (Quercus sp., 37,8 \%), jedli bělokorou (Abies alba, 14,9 \%) a buk lesní (Fagus sylvatica, 14,9 \%). Častěji se objevily uhlíky i borovice lesní (Pinus sylvestris, 9,5\%) a jasanu ztepilého (Fraxinus excelsior, 7,1\%). Dále se vyskytly bř́za (Betula sp., 3,3 \%), lípa (Tilia sp., 3,3\%), habr obecný (Carpinus betulus, 2,9\%), javor (Acer sp., 2,5 \%), vrba (Salix/Populus, 2,5\%) a líska obecná (Corylus avellana, 0,8 \%). Zjištěny byly i tři zuhelnatělé obilky ječmene setého (Hordeum vulgare), dvě zuhelnatělé obilky pšenice seté (Triticum aestivum) a jedno zuhelnatělé semeno hrachu (Pisum sativum). Pestrá druhová skladba včetně náročných listnatých dřevin ukazuje nízkou intenzitu lidského vlivu na okolní prostředí. Výjimku představuje vrstva 102 z tzv. objektu 7/2014 obsahující pouze uhlíky jedle, břízy a vrby. Předpoklad J. Nováka o odlišném původu uloženiny 102 koresponduje s archeologickým pozorováním, podle něhož tato vrstva obsahovala keramiku silně fragmentarizovanou a omletou v terciérním uložení, a naznačující tudíž o něco mladší dataci než keramika z výplní ostatních objektů. 

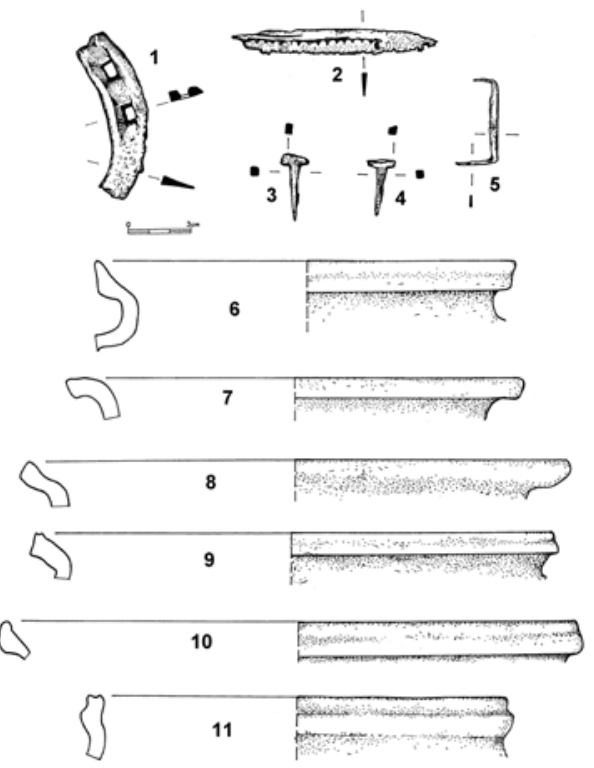

Obr. 21. Vraclav. Nálezy z objektu 7/2014, vrstva 102. Abb. 21. Vraclav. Funde aus Objekt 7/2014, Schicht 102.

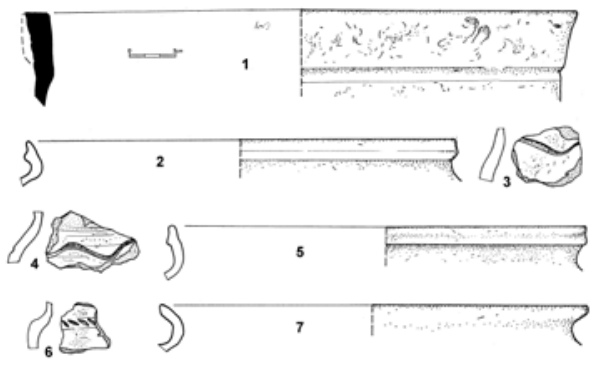

Obr. 22. Vraclav. Nálezy z objektu 7/2014, vrstva 102. Abb. 22. Vraclav. Funde aus Objekt 7/2014, Schicht 102.
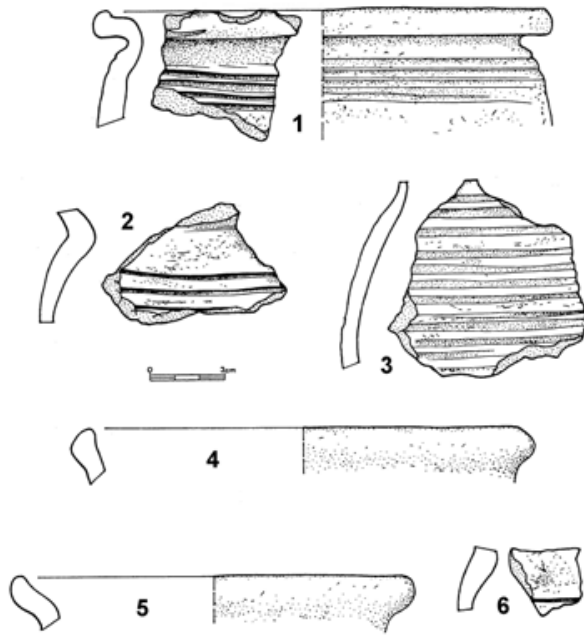

Obr. 23. Vraclav. Nálezy z objektu 7/2014, vrstva 103. Abb. 23. Vraclav. Funde aus Objekt 7/2014, Schicht 103.

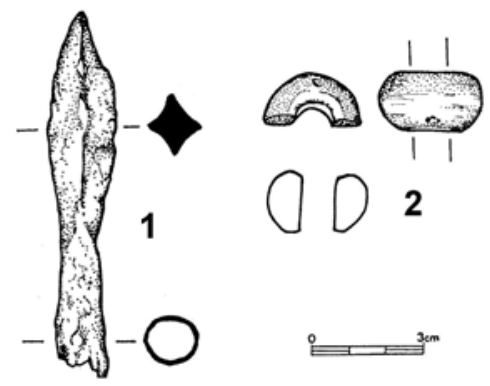

Obr. 24. Vraclav. Výběr nálezů z ruční skrývky, vrstvy 101 a 105 (železný hrot šípu a část keramického přeslenu). Abb. 24. Vraclav. Fundauswahl aus dem manuell beseitigten Abraum, Schicht 101 und 105 (Eisenpfeilspitze und Teil eines Keramikquirls).

\subsection{Nemovité nálezy}

Prozkoumané objekty představují z větší části běžné sídlištní jámy bez možnosti další interpretace. Objekt 3/2014 (jako jediný postrádající movité nálezy) a dvě zahloubeniny v objektu 1/2014 mohou být s jistou opatrností interpretovány jako kủlové jámy. Vzhledem k omezenému rozsahu prozkoumané plochy a umístění těchto objektů při jejím okraji nám ani ony nedovolují učinit si představu o konkrétnější podobě stavební konstrukce. Jako důležitá se př̀i tom jeví skutečnost, že všechny objekty museli lidé v raném středověku s vynaložením značného úsilí zahloubit do rostlého skalního podloží. Situace 7/2014 představuje terénní depresi, přičemž na základě výzkumu daného rozsahu není možné rozhodnout, zda jde o depresi př́rodního původu nebo zda vznikla činností člověka. Povrch deprese kryla mocná uloženina (102) proložená kumulací kamenů označenou jako vrstva 104. Uloženina 102 obsahovala v celém svém objemu ojedinělé železné předměty a množství keramických zlomků, přičemž, jak již bylo řečeno, značná fragmentarizace keramiky projevující se malými rozměry střepů a jejich silnou otřelostí zrretelně signalizuje její terciérní původ. Bázi situace v objektu 7/2014 pak tvořila uloženina 103 obsahující ojedinělé, ale naopak větší zlomky keramiky - tato vrstva tedy s největší pravděpodobností složitějšími postdepozičními procesy neprošla. Vzhledem k tomu, že terciérně uložené vrstvy 
obsahovaly keramiku z mladší doby hradištní, ale ještě nikoliv nálezy vrcholně středověké či novověké (hojně naopak obsažené v navážkách a ornici - uloženiny 101 a 105), vzniklo toto souvrství v průběhu zániku hradiště či relativně nedávno po této události. Ojedinělé subrecentní artefakty se ve vrstvě 102 objevily pouze v sondě 3/2014 při stěně domu čp. 112, kam se nepochybně dostaly jako důsledek hloubení jeho základů.

\section{Zhodnocení a interpretace výsledků výzkumu}

Výzkum, který je zároveň prvním plošným výzkumem na předhradí raně středověkého vraclavského hradiště (a poněkud neskromně dodejme, že zatím také prvním publikovaným výzkumem z hradiště vůbec), zachytil kůlové jámy (?) a další běžné sídlištní jámy bez možnosti konkrétní interpretace (přičemž obj. 2/2014 narušil recentní pohřeb psa současných majitelů). Starší, pravěké situace a nálezy (s výjimkou rezidua silicitového jádra nalezeného ve vrstvě 102) na rozdíl od pozorování V. Vokolka při sledování výkopu pro vodovod v roce 1954 registrovány nebyly. Vzhledem k tomu, že movité pravěké nálezy máme vedle akropole doloženy povrchovými sběry i na předhradí, je tento stav patrně pouze výsledkem omezeného rozsahu zkoumané plochy. Nejzajímavější se jeví situace označená jako obj. 7/2014 představující depresi zaplněnou především vrstvou 102 představující splach s nálezy v terciérním uložení. Rozsah výzkumu však nedovoluje vyslovit se více k původu a vzniku této situace. Výplň zkoumaných situací obsahovala keramiku podávající dobrou představu o místní hrnčířské produkci, mimo to poskytla i zajímavý soubor kalichovitých okrajů. Výskyt kalichovitých okrajů ve východních Čechách, jejich datování a srovnání s pražskou produkcí musí být předmětem dalšího výzkumu.

Kresebná dokumentace nemovitých objektů a situací D. Vích (nivelety v bpv); kresby všech movitých nálezů K. Urbanová.

\section{Prameny a literatura}

BEKOVÁ, M., 1999: Slovanské pohřebiště ve Vraclavi, okr. Ústí nad Orlicí - Slawisches Gräberfeld in Vraclav, Kr. Ústí nad Orlicí, Studia Mediaevalia Pragensia IV, 67-74.

BOHÁČOVÁ, I., 2001: Pražský hrad a jeho nejstarší opevňovací systémy. In: Pražský hrad a Malá Strana. Mediaevalia archaeologica 3 (Ježek, M.-Klápště, J., edd.), 179-301. Praha.

- 2003: Záchranný archeologický výzkum od r. 1988 - History of the archaeological excavations prior to 1988. In: Stará Boleslav. Přemyslovský hrad v raném středověku. Mediaevalia archaeologica 5 (Boháčová, I., ed.), 37-55. Praha.

- 2003a: Keramika - Ceramics. In: Stará Boleslav. Přemyslovský hrad v raném středověku. Mediaevalia archaeologica 5 (Boháčová, I., ed.), 393-454. Praha.

BOHÁČOVÁ, I.-ČIHÁKOVÁ, J., 1994: Gegenwärtiger Stand des Entwicklungsschemas der Prager frühmittelalterlichen Keramik aus den ältesten Entwicklungsphasen der Prager Burg und ihrem Suburbium auf dem linken Moldau-Ufer. In: Tomková, K. a kol., Zum gegenwärtigen Stand des Studiums der frühmittelalterlichen Keramik in Mittelböhmen. In: Slawische Keramik in Mitteleuropa vom 8. bis 11. Jahrhundert. Internationale Tagungen in Mikulčice I. (Staňa, Č., ed.), 173-177. Brno.

ČIHÁKOVÁ, J., 1984: Pražská keramika 12.-13. století, Archaeologica Pragensia 5, 257-262.

- 1997: Sdělení o archeologickém a palynologickém výzkumu v Praze - Malé Straně (čp. 259/III) - Mitteilung über die archäologische und palynologische Untersuchung in Prag-Kleinseite (Nr. 259/III). In: Život v archeologii středověku. Sborník příspěvků věnovaných Miroslavu Richterovi a Zdeňku Smetánkovi, 120-129. Praha.

ČTVERÁK, V.-LUTOVSKÝ, M.-SLABINA, M.-SMEJTEK, L., 2003: Encyklopedie hradišst’ v Čechách. Praha.

DEMEK, J.-MACKOVČIN, P., edd., 2006: Hory a nížiny. Zeměpisný lexikon ČR. Brno.

DRESLEROVÁ, G., 2015: Vraclav - archeozoologická analýza. Nepublikovaná zpráva ulož. v Regionálním muzeu ve Vysokém Mýtě.

FROLÍK, J.-SIGL, J., 1995: Chrudimsko v raném středověku. Vývoj osídlení a jeho proměny. Hradec Králové. 
GOŠ, V., 1977: Slovanská keramika 10.-13. století na severní Moravě, VVM XXIX, 291-303.

HOŠEK, J.-ŠILHOVÁ, A., 2006: Metalograficko-restaurátorské průzkumy raně středověkých nožů - The metallographico-restoration survey of Early Medieval knives, AR LVIII, 59-75.

HRDLIČKA, L., 1993: Poznámky ke chronologii pražské středověké keramiky - Bemerkungen zur Chronologie der Prager mittelalterlichen Keramik, AR XLV, 93-112.

- 1997: K výpovědi stratigrafického vývoje Pražského hradu - Zur Aussagekraft der stratigraphischen Entwicklung der Prager Burg, AR XLIX, 649-662.

JEŽEK, M.-SIGL, J.-VOKOLEK, V., 1998: Výzkum bývalého kostela sv. Václava ve Vraclavi, Zpravodaj muzea v Hradci Králové 24, 111-126.

JEŽEK, M.-SOMMER, J., 2001: Bývalý kostel sv. Václava ve Vraclavi, PRP VIII, č. 2, 97-109.

CHARVÁT, P., 1978: Slovanské osídlení Vraclavska do poloviny 13. století. Kandidátská disertace ulož. ve Státním okresním archivu Svitavy se sídlem v Litomyšli, sbírka vědeckých a literárních rukopisů, sign. R 196.

NOVÁK, J., 2015: Vraclav 2 - úpravy terénu u čp. 112. Antrakologická a makrozbytková analýza. Nepublikovaná zpráva ulož. v Regionálním muzeu ve Vysokém Mýtě.

PAVLŮ, I., 1971: Pražská keramika dvanáctého a třináctého století. Praehistorica IV. Praha.

PÍČ, J. L., 1909: Starožitnosti země České. Díl III. Čechy za doby knížecí 1. Část archeologická. Praha.

PROCHÁZKA, R.-PEŠKA, M., 2007: Základní rysy vývoje brněnské keramiky ve 12.-13./14. století, PV 48, 143-299.

RICHTER, M., 1994: Hrnčířská pec ze Starého Mýta (k otázce počátků vrcholně středověké keramiky) Töpferofen aus Staré Mýto (zur Frage der Anfänge der hochmittelalterlichen Keramik). In: Mediaevalia archaeologica Bohemica 1993. PA - Supplementum 2, 145-157. Praha.

RICHTER, M.-VOKOLEK, V., 1995: Hradec Králové. Slovanské hradiště a počátky středověkého města. Hradec Králové - Praha.

SKRUŽNÝ, L., 1962: Dějiny vraclavského hradiska, Zprávy Východočeského muzea v Pardubicích 1962, 8-13.

SLÁMA, J., 1986: Střední Čechy v raném středověku. Praehistorica XI. Praha.

SMETÁNKA, Z., 1973: Př́íspěvek k chronologické problematice pozdní doby hradištní - Ein Beitrag zur Problematik der Chronologie der späten Burgwallzeit, PA LXIV, 463-486.

VÁLEK, B., 1964: Půdy východních Čech. Havlíčkův Brod.

VÍCH, D., 2000: Raně středověké nálezy z Vraclavska, Zpravodaj muzea v Hradci Králové 26, 57-96.

- 2004: Středověké nálezy z povrchových sběrů na k. ú. Tisová (okr. Ústí nad Orlicí), Zpravodaj muzea v Hradci Králové 30, 212-225.

- 2008: Archeologický výzkum při přístavbě ZŠ ve Vraclavi - Early medieval finds obtained during the rescue archaeological excavation at Cerekvice nad Loučnou, Svitavy district, ASČ 12, 773-776.

- 2008a: Raně stř̌edověké nálezy získané při záchranném archeologickém výzkumu v Cerekvici nad Loučnou (okr. Svitavy) - Early medieval finds obtained during the rescue archaeological excavation at Cerekvice nad Loučnou, Svitavy district, ASČ 12, 693-699.

- 2010: Středověká studna ve Vraclavi - Medieval well in Vraclav, Eastern Bohemia, AR LXII, 348-358.

-2012: Raně středověké archeologické nálezy z k. ú. Říkovice (okr. Svitavy) - Early medieval archaeological finds from cadastral territory of Ř́kovice (district of Svitavy), Archeologie východních Čech 1 (2011), 100-109.

VOKOLEK, V., 1954: Vraclav, Nálezová zpráva č. j.2845/54 ulož. v archivu ARÚ AV ČR, Praha, v. v. i.

- 1996: Středověké nálezy z Vraclavi, Zpravodaj muzea v Hradci Králové 22, 71-77.

\section{Zusammenfassung}

\section{Die archäologische Rettungsgrabung auf der Vorburg des Wratzlauer Burgwalls}

Das Katastergebiet Vraclav/Wratzlau (Bezirk Ústí nad Orlicí/ Wildenschwert, Kreis Pardubice/Pardubitz) befindet sich ganz in der Spitze des Wratzlauer Bergrückens, der die Leitomischler Senke vom Chrudimer Tafelland trennt (Demek-Mackovčin 2006). Der Burgwall liegt auf einem Bergsporn oberhalb eines tief eingeschnittenen Tals. Im 11. Jahrhundert entstand dort ein Burgwall, der die Funktion eines Machtzentrums der herrschenden Přemysliden erfüllte. Zu Beginn des 14. Jahrhunderts wird der Burgwall bereits als wüst erwähnt (zu den schriftlichen Quellen vgl. Sláma 1986, 94; Übersicht der Grabungen an der Fundstelle vgl. 
Vích 2010). Integrierter Bestandteil des Burgwalls war auch eine Vorburg, über die wir bislang praktisch keine Erkenntnisse hatten.

Die Situation bezüglich der Gewinnung von Erkenntnissen über die Vorburg wurde erst durch ein Vorhaben der Besitzer des Hauses mit der Konskriptionsnummer 112 ein wenig verändert. Deren Haus befindet sich unterhalb einer künstlichen Felswand zwischen Akropolis und Vorburg. Für die Bewohner des Hauses stellte durch losgelöste Steine verursachter Steinfall eine Bedrohung dar. Das Problem sollte durch eine Einböschung der betreffenden Wand unter Einbeziehung eines ca. $3 \mathrm{~m}$ breiten Streifen unberührten Geländes gelöst werden. Dies führte dazu, dass von den Mitarbeitern des Regionalmuseums in Vysoko Mýto im Juni und Juli 2014 eine archäologische Rettungsgrabung durchgeführt wurde.

Die für die archäologische Grabung bestimmte Fläche wurde in die Sondiergrabungen 1-3/2014 unterteilt (Abb. 2-3). Die Abraumarbeiten wurden von Hand und ohne die Verwendung schwerer Technik durchgeführt. Es zeigte sich, dass die Ackerkrume und die Schichten rezenten Alters auf einem Pläneruntergrund auflagen, in welchen archäologische Objekte eingetieft worden waren. Insgesamt konnten sieben Objekte (1-6, 8/2014, Abb. 4) und der mit tertiär gelagerten Sedimenten gefüllte, abschüssige Felsenuntergrund (als Objekt 7/2014 bezeichnet, Abb. 5-6) untersucht und dokumentiert werden.

Aus der Grabung stammt eine Kollektion von in das 11.-12. Jahrhundert datierter Keramik, die Schichten der Situation 7/2014 enthielten stark verschlissene Keramik vom Ende des frühen Mittelalters. Neben der lokalen Keramikproduktion begegnet man dort auch Keramikbruchstücken aus Mittelböhmen (Abb. 9:5, 7-8; 10:7; 11:8; 14:2, 11; 17:6), fraglich bleibt die Herkunft von einigen Bruchstücken mit ungewöhnlicher Verzierung (Abb. 10:6; 20:4). Gegenstände aus Eisen sind durch Messer, ein Hufeisenfragment u.a. vertreten (Abb. 21:1-5) und können nicht näher datiert werden. Aus den Überschüttungsschichten stammt eine Pfeilspitze aus dem Hochmittelalter und der Teil eines Quirls (Abb. 24).

Von den Küchenabfälle darstellenden Tierknochenfragmenten konnten vor allem die Tiere Auerochse (Bos primigenius $f$. taurus), Schwein (Sus scrofa $f$. domestica) und Schaf/Ziege (Ovis-Capra) identifiziert werden. Das Pferd (Equus caballus) ist durch einen Zahn vertreten, und durch einen Oberarmknochen auch der Hund (Canis lupus f. familiaris), ein Knochen stammt von der Hausgans (Anser anser f. domesticus). Die Kohlenstoffanalyse deutet auf eine geringe Intensität menschlichen Einflusses auf die benachbarte Umgebung hin, eine Ausnahme davon stellt lediglich Schicht 102 aus Situation 7/2014 dar.

Bei der Grabung wurden Pfahlgruben (?) und weitere gängige Siedlungsgruben entdeckt (wobei Obj. 2/2014 durch die rezente Bestattung eines Hundes der derzeitigen Besitzer gestört wurde). Es wurden keine urzeitlichen Situationen registriert. Am Interessantesten erscheint die als Obj. 7/2014 bezeichnete Situation, wobei es sich um eine Depression handelt, die mit der aus Anschwemmungen mit tertiär gelagerten Funden bestehenden Schicht 102 gefüllt ist. Der Umfang der Grabung erlaubt es jedoch nicht, sich näher zu Herkunft und Entstehung dieser Situation zu äußern.

Zeichendokumentation unbeweglicher Objekte und Situationen D. Vích (Gradienten im Baltischen Höhensystem); Zeichnungen aller beweglichen Funde K. Urbanová.

PhDr. David Vích, Regionální muzeum ve Vysokém Mýtě, Šemberova 125, 56601 Vysoké Mýto, Česká republika,dvich@centrum.cz 